\title{
Facial morphometry of Ecuadorian patients with growth hormone receptor deficiency/Laron syndrome
}

G B Schaefer, A L Rosenbloom, J Guevara-Aguirre, E A Campbell, F Ullrich, K Patil, J L Frias

\begin{abstract}
Facial morphometry using computerised image analysis was performed on patients with growth hormone receptor deficiency (Laron syndrome) from an inbred population of southern Ecuador. Morphometrics were compared for 49 patients, 70 unaffected relatives, and 14 unrelated persons. Patients with growth hormone receptor deficiency showed significant decreases in measures of vertical facial growth as compared to unaffected relatives and unrelated persons with short stature from other causes. This report validates and quantifies the clinical impression of foreshortened facies in growth hormone receptor deficiency.
\end{abstract}

( $\mathcal{F}$ Med Genet 1994;31:635-639)

A syndrome of severe growth failure with facial features that resembled growth hormone $(\mathrm{GH})$ deficiency, but with high levels of $\mathrm{GH}$ in the serum, was described initially in 1966 by Laron et al. ${ }^{1}$ Affected subjects were Oriental Jews from largely consanguineous unions. ${ }^{2}$ Administration of exogenous $\mathrm{GH}$ failed to stimulate somatomedin (IGF-I) production, ${ }^{3}$ indicating a defect in cellular response to $\mathrm{GH}$ which was eventually proven to be the result of failure of the $\mathrm{GH}$ receptor. ${ }^{45}$ Some 180 patients have been described with growth hormone receptor deficiency (GHRD)/Laron syndrome, of whom all but a few are of Mediterranean or Middle Eastern origin, and nearly $70 \%$ are semitic. These numbers include 65 patients from a small region (120 km diameter) of southern Ecuador who are inbred white Spaniards with names that indicate that they are conversos, Jews who became Catholics during the Inquisition. ${ }^{6}$

Affected persons have been described as having "acromicria", defined as small hands, feet, and faces. Craniofacial disproportion was described and quantified as an abnormal difference between the biparietal and bicondylar diameter compared to normal. ${ }^{7}$ We questioned whether the face might appear small because it is proportionate to body size while the more normal head appears macrocephalic (fig 1). ${ }^{8}$ This craniofacial disproportion is particularly striking in young children, who often also have the "setting sun sign", the appearance of sclera above the iris. These findings may be so striking that hydrocephalus is suspected.

There has been recent interest in the application of quantitative facial morphometrics techniques in clinical genetics, resulting primarily from two factors: (1) dramatic improvement in microcomputer technology producing affordable, readily available processing of extremely complex algorithms, (2) refinement, adaptation, and simplification of previous morphometric techniques with a great reduction in systematic errors, ${ }^{9-13}$ and (3) the availability of large age and sex matched normative data. ${ }^{14} 15$ Such techniques have been applied to a variety of specific clinical entities to answer questions about craniofacial characteristics in conditions such as Crouzon syndrome, ${ }^{16}$ fetal alcohol syndrome, ${ }^{17}$ $\mathrm{X}$ linked hypohidrotic ectodermal dysplasia, ${ }^{18}$ Angelman syndrome, ${ }^{19}$ in utero exposure to marijuana, ethanol, and cocaine, ${ }^{20}$ cleft lip and palate, ${ }^{21}$ Down's syndrome, ${ }^{22}$ hemifacial microsomia, ${ }^{23}$ Prader-Willi syndrome, ${ }^{24}$ fragile $\mathrm{X}$ syndrome, ${ }^{25}$ Treacher Collins syndrome, ${ }^{26}$ and Apert syndrome. ${ }^{27}$ We report the results of facial morphometric analysis of 49 Ecuadorian patients with GHRD.

Examination of photographs of patients with GHRD suggested that their abnormality was not in overall facial size, but in the vertical dimension and that this was the principal feature giving the appearance of craniofacial disproportion (fig 1). This study was designed to quantify facial dimensions and analyse head size data in these patients.

\section{Materials and methods}

SUBJECTS

Probands with GHRD included 15 males and 34 females proven to be homozygous for the codon 180 mutation of the GHR gene. ${ }^{28}$ Their mean age was 22.3 years. Sixty-nine of the first and second degree relatives ( 24 male, $45 \mathrm{fe}$ male, mean age 23.2 years) and 16 unrelated Ecuadorian patients with other causes of short stature (eight male, eight female, mean age 14.2 years) served as controls. Most of the latter group had $\mathrm{GH}$ deficiency which had been under treatment with GH injections.

\section{CRANIAL MEASUREMENT}

Head circumference measurements of probands were compared to standards for chronological age, osseous maturation (in those under 18 years of age), ${ }^{29}$ height, and age, and were expressed as standard deviation scores (SDS).$^{30}$ For this portion of the study, all head circumference data were analysed, comprising measurements from 60 probands. Statistical comparisons were made using single tailed tests. 


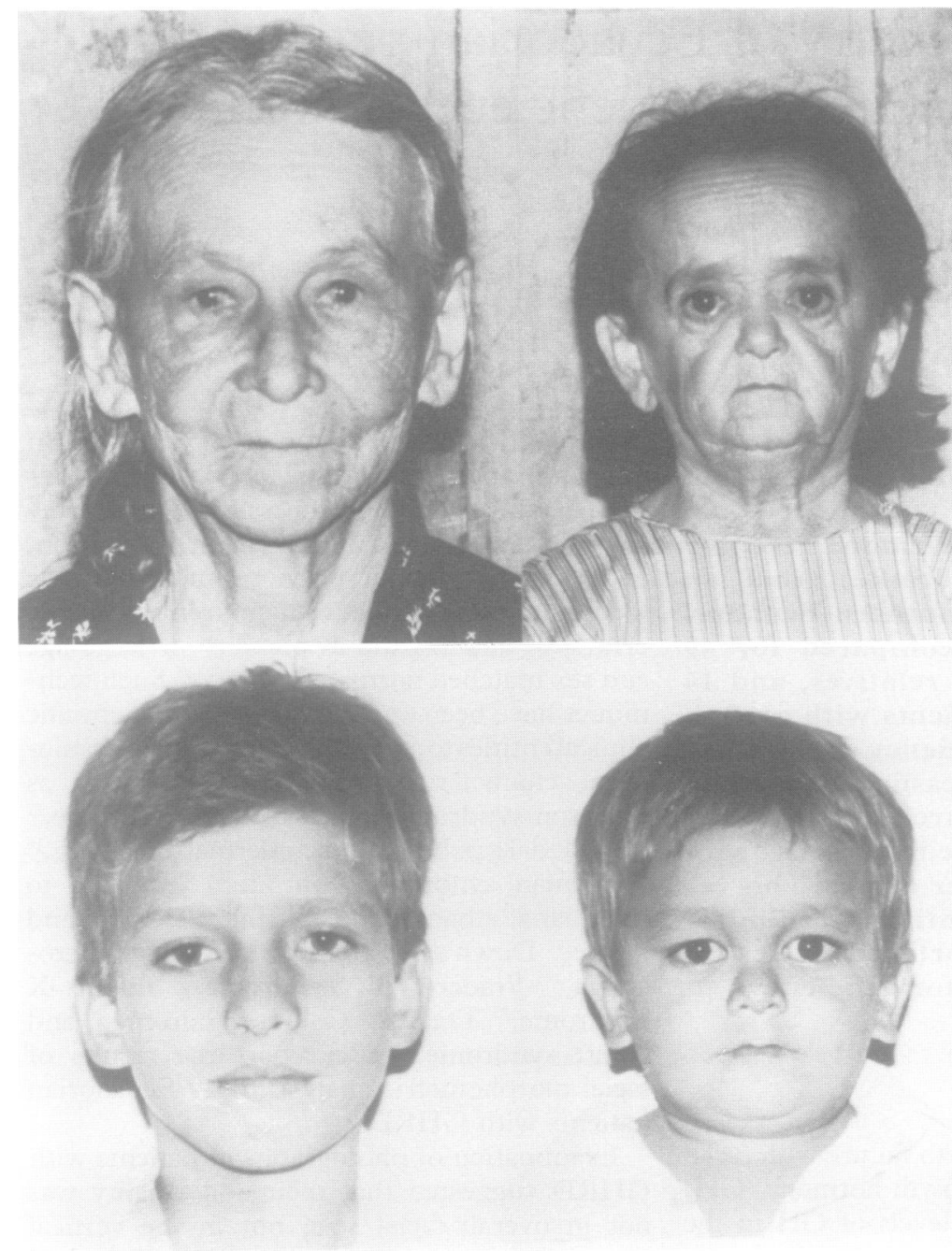

Figure 1 Photographs taken at the same distance of a 52 year old patient (upper right), her 76 year old unaffected mother (upper left), a 9 year old patient (lower right), and his unaffected 11 year old brother (lower left).
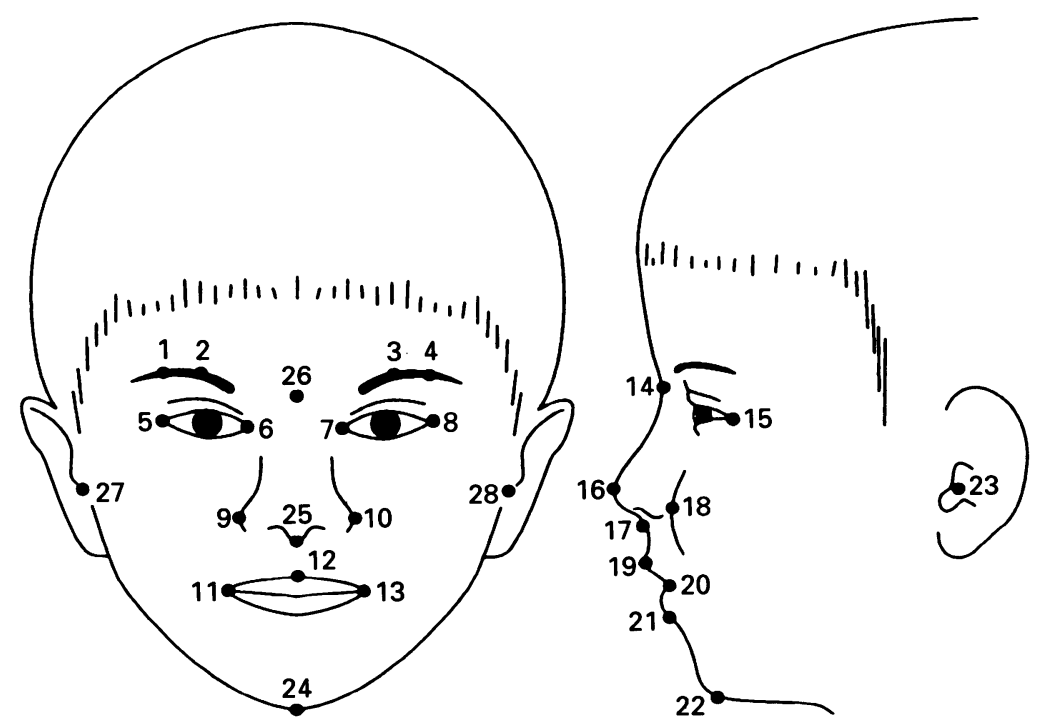

Figure 2 Clinical landmarks used in facial morphometrics in this study (after Claren et $a l^{17}$ ).

\section{PHOTOGRAPHY}

All subjects were photographed with a single lens reflex $35 \mathrm{~mm}$ camera using a $135 \mathrm{~mm}$ lens at a distance of exactly $2 \cdot 4 \mathrm{~m}$. Frontal and lateral pictures with no detectable rotation were printed to scale as standard $5 \times 7$ glossy prints.

\section{COMPUTERISED FACIAL MORPHOMETRICS}

Photographic images were input into the computer via a high resolution black and white video camera. Images were captured and digitised using a DT 2851 Frame Grabber and DT 2858 auxiliary math coprocessor board (Data Translation, Wellesly, MA) and Image ProII (Media Cybernetics, Silver Spring, MD) software. Morphometrics were accomplished with Image Measure IP/2500 add in morphometry module (MicroScience, Federal Way, WA).

Analysis of facial features was carried out using the triangulation methods developed by Bookstein. ${ }^{31}{ }^{32}$ We used the 23 landmark points defined by Claren et $a l^{1720}$ and an additional five points that we chose based upon our suspicion of areas of the face that might have altered development in our particular patients (fig 2).

In brief, the triangulation method uses an internal relative scale. Two strategic reference points are chosen (for example, points 1 and 4, fig 2) and digitised. The first point is assigned the value of the origin $(X=0, Y=0)$, the second point is given the value $X=0, Y=1$. Thereafter, the digitised $\mathrm{X}$ and $\mathrm{Y}$ coordinates of any other point represent a relative distance and direction from the established axis. These methods are detailed elsewhere. ${ }^{17203132}$ Because the triangulation method uses a relative scale, most potential sources of non-random measurement variability (for example, slight differences in distance and angle of the photographic line) are trivialised. In fact, in our replicate studies the inter- and intra-investigator variability was consistently less than $0.5 \%$.

\section{STATISTICAL ANALYSIS}

Morphometry of each landmark (triangle) was compared between the three groups by use of multivariate analysis of variance. When this analysis showed significant differences, a contrast method was used to assess which of the coordinates, $\mathrm{X}$ or $\mathrm{Y}$ or both, differed pairwise between the groups. These results were also examined with Scheffe's test. The statistical significance was noted at $\mathrm{p}<0.01$.

\section{Results}

CRANIAL SIZE (FIG 3)

The head circumference SDS means for chronological age and height age were separately determined for children (under 18 years, $\mathrm{n}=30)$ and adults $(\mathrm{n}=30)$. There were similar means for chronological age in these two groups (-3.1 (SD 1.2), -3.3 (SD 1.7)). Their means can be compared to the statural SDS mean of -8.4 (SD 1.5), suggesting greater 


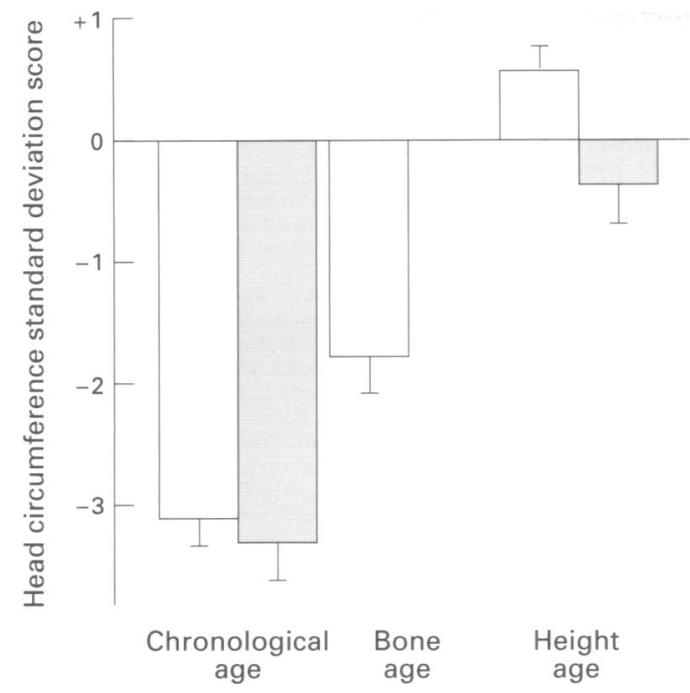

Figure 3 Mean head circumference standard deviation score (SDS) for chronological age, bone age, and height age in 30 children ( $<18$ years of age) (open bars) and for chronological and height age in 30 adults (shaded bars) with growth hormone receptor deficiency. Extensions from the bars represent standard error. Child and adult means for chronological age are not different, but SDS means for height age differed significantly $(p<0.01)$

Facial morphometric comparisons between patients with GHRD (group 3, $n=49$ ), unaffected relatives (group $2, n=69$ ), and unrelated persons (group $1, n=16$ )

\begin{tabular}{|c|c|c|c|c|c|c|}
\hline & Group 3 & $v$ & group 2 & Group 3 & $v$ & group 1 \\
\hline Triangle & Coordinate & $I / D$ & $p$ & Coordinate & $I / D$ & $p$ \\
\hline $\begin{array}{l}1-4-12 \\
1-4-24 \\
1-4-25 \\
1-4-26\end{array}$ & $\begin{array}{l}\mathrm{Y} \\
\mathrm{Y} \\
\mathrm{Y} \\
\mathrm{Y}\end{array}$ & $\begin{array}{l}\text { D } \\
\text { D } \\
\text { D }\end{array}$ & $\begin{array}{c}0.0001 \\
0.0001 \\
0.0001 \\
\text { NS }\end{array}$ & $\begin{array}{l}\mathrm{Y} \\
\mathrm{Y} \\
\mathrm{Y} \\
\mathrm{Y}\end{array}$ & $\begin{array}{l}\text { D } \\
\text { D } \\
\text { D } \\
\text { D }\end{array}$ & $\begin{array}{l}0.0001 \\
0.0001 \\
0.0001 \\
0.0057\end{array}$ \\
\hline $9-10-26$ & $\mathbf{Y}$ & D & 0.0064 & & & NS \\
\hline $\begin{array}{l}27-28-12 \\
27-28-24 \\
27-28-25\end{array}$ & $\begin{array}{l}\mathrm{Y} \\
\mathrm{Y} \\
\mathrm{Y}\end{array}$ & $\begin{array}{l}\text { D } \\
\text { D } \\
\text { D }\end{array}$ & $\begin{array}{l}0.0002 \\
0.001 \\
0.0019\end{array}$ & $\mathbf{Y}$ & $\mathrm{D}$ & $\begin{array}{r}\text { NS } \\
0.001 \\
\text { NS }\end{array}$ \\
\hline $\begin{array}{l}\text { 6- } 7-24 \\
6-7-25\end{array}$ & $\mathbf{Y}$ & D & $\begin{array}{c}\text { NS } \\
0.0001\end{array}$ & $\begin{array}{l}\mathrm{Y} \\
\mathrm{Y}\end{array}$ & $\begin{array}{l}\mathrm{D} \\
\mathrm{D}\end{array}$ & $\begin{array}{l}0.0093 \\
0.0001\end{array}$ \\
\hline $\begin{array}{l}5-8-24 \\
5-8-25\end{array}$ & $\begin{array}{l}\mathbf{Y} \\
\mathbf{Y}\end{array}$ & $\begin{array}{l}\text { D } \\
\text { D }\end{array}$ & $\begin{array}{l}0.00019 \\
0.0001\end{array}$ & & & $\begin{array}{l}\text { NS } \\
\text { NS }\end{array}$ \\
\hline $\begin{array}{l}14-18-23 \\
14-19-18\end{array}$ & $\mathbf{x}$ & D & $\begin{array}{r}\text { NS } \\
0.002\end{array}$ & $\begin{array}{l}\mathbf{Y} \\
\mathbf{X}\end{array}$ & $\begin{array}{l}\text { I } \\
\text { D }\end{array}$ & $\begin{array}{l}0.0019 \\
0.002\end{array}$ \\
\hline $\begin{array}{l}22-19-18 \\
22-17-14 \\
22-17-14\end{array}$ & $\begin{array}{l}\mathrm{X} \\
\mathrm{Y} \\
\mathrm{X}\end{array}$ & $\begin{array}{l}\text { D } \\
\text { D } \\
\text { D }\end{array}$ & $\begin{array}{l}0.00059 \\
0.0001 \\
0.0008\end{array}$ & $\begin{array}{l}\mathrm{X} \\
\mathrm{Y} \\
\mathrm{X}\end{array}$ & $\begin{array}{l}\mathrm{D} \\
\mathrm{D} \\
\mathrm{D}\end{array}$ & $\begin{array}{l}0.00059 \\
0 \cdot 0001 \\
0 \cdot 0008\end{array}$ \\
\hline
\end{tabular}

$I=$ increased, $\mathbf{D}=$ decreased. between affected subjects with GHRD (group 3) and unaffected first or second degree relatives (group 2). It was particularly attractive initially to compare these two groups as they had nearly identical age distributions, the same 2:1 female predominance (as previously reported), and the ability to use relatives to correct for any familial facial differences. When the two groups were compared, numerous strongly significant differences were noted (table). All of these differences have in common a decrease in the absolute vertical dimension of the entire face, most impressively in the midface region. When patients in group 3 were compared to those in group 1 (unrelated subjects with short stature from other causes) the findings were similar to comparisons with group 2 (table). Again, the findings were suggestive of a decreased vertical dimension of the entire face in patients with GHRD.

Comparison of unaffected relatives (group 2) to unrelated controls with other causes of short stature (group 1) showed only two significant differences. Group 1 as compared to group 2 had an increase in the $\mathrm{Y}$ coordinate of triangle $14-16-17(p=0.0001)$ and a decrease in the $Y$ of triangle 14-19-18 $(p=0.001)$. Neither of these findings relates to the changes noted in the patients with GHRD, which supports the notion that the findings above are clinically significant.

\section{Discussion}

These data (table) show a striking decrease in vertical facial growth in patients with GHRD. When patients with GHRD (group 3) are compared to their unaffected relatives (group 2), all measures of vertical facial dimensions, with the exception of triangle 6-7-24 (fig 2) were significantly reduced. The measurements for this triangle bordered on statistical significance $(p=0.07)$ but there was a relatively large variance in their parameters which negated significance. It is not certain why the dimensions of this particular triangle should show such a large degree of variance. One possible explanation could be that the reference line (6-7), a measure of inner canthal distance, simply has a naturally occurring large degree of variance within this kinship. Regardless, the clear pattern from these data is that vertical facial growth is markedly foreshortened in patients with GHRD.

When we compared patients with GHRD to unrelated persons (group 1) with short stature on the basis of other problems (mainly $\mathrm{GH}$ deficiency) we found similar results (table). It is interesting that triangle 6-7-24 was significantly different in this comparison, again suggesting some inherent degree of variability in the kinship studied. Five measures (triangles 9-10-26, 27-28-25, 27-28-12, 5-8-25, and 5-8-24), which were significantly different when group 3 (patients with GHRD) was compared to group 2 (unaffected relatives), were not different when groups 3 and 1 were compared. This may be in part because of the fact that groups 2 and 3 have similar mean ages and a 2:1 female to male ratio, while group 1 had a smaller mean age and a 1:2 
male to female ratio. Comparison of group 2 to group 1 showed no differences in vertical facial dimensions, however. As mentioned previously, group 1 consisted largely of patients with GH deficiency; all patients in this group had a height of less than 2 SDS from the age appropriate mean, whereas group 2 all had normal stature. Thus, the difference seen in our patients with GHRD cannot be explained on the basis that they simply had a shorter total body height.

We have previously noted that head circumference SDS for chronological age was much less abnormal than height SDS in persons with GHRD in Ecuador. This discrepancy was thought to contribute to the appearance of a large cranium and small facies. Cranial circumference is, however, normal for height age in these patients, indicating that the comparison of head circumference SDS and height SDS is inappropriate because of the different magnitudes of growth in head size and body length. For example, there is a $12 \%$ increase in head circumference from 2 years to maturity in males while there is a greater than $100 \%$ increase in stature during this time. Thus, the head is not relatively large, but normal for body size. The impression of macrocephaly, particularly in young children, appears to reflect the reduction in vertical dimension of the face, the hypoplastic nasal bridge, and the normal width and height of the forehead. We found that the children did have relatively larger heads for height age compared to affected adults, consistent with clinical impressions of head size seeming greater in the children, relative to stature.

We have previously noted that arm span and lower segment are reduced in adults with GHRD.$^{8334}$ Children had normal arm spans and ratios of upper to lower body segments. The development of the facial bones may reflect maturational delay in the children and the disproportion in the long bones in adults. Growth of the skull would be expected to respond to brain growth with, however, delay in closure of the fontanelles which is a feature of GHRD. The fact that head size is proportionate to stature thus indicates an important influence of the GH-GH receptor-IGF-I axis on overall brain size. This does not, however, appear to be an influence of sufficient magnitude to affect intelligence. ${ }^{34}$

The availability of recombinant human IGFI has made it possible to initiate trials of therapy of children with GHRD. The effects of this therapy on craniofacial growth will be of great interest.

1 Laron Z, Pertzelan A, Mannheimer S. Genetic pituitary dwarfism with high serum concentration of growth hormone - a new inborn error of metabolism? Isr $\mathcal{f}$ Med Sci mone - a new
$1966 ; 2: 152-5$.

2 Perzelan A, Adam A, Laron Z. Genetic aspects of pituitary dwarfism due to absence or biological inactivity of growth dwarfism due to absence or biological inacti

3 Laron Z, Pertezelan A, Karp M, Kowaldo-Silbergeld A Doughaday WH. Administration of growth hormone to patients with familial dwarfism with high plasma immupatients with familial dwarfism with high plasma immu- factor, metabolic and linear growth responses. $f$ Clin Endocrinol Metab 1971;33:332-42.

4 Eshet R, Laron Z, Pertzelan A, Arnon R, Dintzman M Defect of human growth hormone receptors in the liver of two patients with Laron-type dwarfism. Isr $7 \mathrm{Med} S c i$ 1984;20:8-11.

5 Godowski PJ, Leung DW, Meacham LR, et al. Characterization of the human growth hormone receptor gene and demonstration of a partial gene deletion in two patients with Laron-type dwarfism. Proc Natl Acad Sci USA with Laron-type

6 Rosenbloom AL, Guevara-Aguirre J, Fielder PJ, et al. Growth hormone receptor deficiency/Laron syndrome in Ecuador: clinical and biochemical characteristics. In: Ecuador: clinical and biochemical characteristics. In:
Laron Z, Parks JS, eds. Lessons from Laron syndrome Laron Z, Parks JS, eds. Lessons from Laron syndrome (LS) 1966-1992. Pediatric and Adolescer

7 Laron Z. Laron-type dwarfism (hereditary somatomedin deficiency): a review. In: Frick $H$, von Harnack $G A$, Kochsiek K, Martini GA, Prader A, eds. Advances in internal medicine. Heidelberg: Springer-Verlag, 1984:117-50.

8 Guevara-Aguirre J, Rosenbloom AL, Vaccarello MA, et al. Growth hormone receptor deficiency (Laron syndrome) clinical and genetic characteristics. Acta Paediatr Scand (Suppl) 1991;377:96-103.

9 DiLiberti JH, Olson DP. Photogrammetric evaluation in clinical genetics: theoretical considerations and experimental results. Am $₹$ Med Genet 1991;39:161-6.

10 DiLiberti JH. Application of D'Arcy Thompson's coordinate transformation approach to clinical genetics photographs using image processing techniques. $\mathcal{f}$ Med Genet graphs using ima

11 Ward RE. Facial morphology as determined by anthropometry: keeping it simple. 7 Craniofac Genet 1989;9:45-60.

12 Thomas IT, Hintz RJ, Frias JL. New methods for quantitative and qualitative facial studies: an overview. $\mathcal{f} \mathrm{Cra}$ niofac Genet 1989;9:107-11.

13 Matteson SR, Bechtold W, Phillips C, Staab EV. A method for three dimensional image reformation for quantitative cephalometric analysis. $\mathcal{f}$ Oral Maxillofac Surg 1989;47:1053-61.

14 Farkas LG, Cheung G. Facial asymmetry in healthy North American Caucasians. An anthropometrical study. Angle Orthod 1981;51:70-7.

15 Farkas LG, Kolar JC. Anthropometrics and art in the aesthetics of women's faces. Clin Plast Surg 1987;14:599616

16 Richtsmeier JT, Lele S. Analysis of craniofacial growth in Crouzon syndrome using landmark data. $\mathcal{f}$ Craniofac Genet Dev Biol 1990;10:39-62.

17 Claren SK, Sampson PD, Larsen J, et al. Facial effects of fetal alcohol exposure: assessment by photographs and morphometric analysis. Am $\mathcal{f}$ Med Genet 1987;26:651-66.

18 Saksena SS, Bixler D. Facial morphometrics in the identification of X-linked hypohidrotic ectodermal dysplasia. $A m$ 7 Med Genet 1990;35:105-14.

19 Frias JL, Schaefer GB, Gray B, Williams CA. Morphometric analysis of facial features in patients with Angelman syndrome. Proceedings and abstracts of the 12th annual David $W$ Smith workshop on malformation and morphogenesis. Lake Arrowhead, California, 1991

20 Astley SJ, Clarren SK, Little RE, Sampson PD, Daling JR. Analysis of facial shape in children gestationally exposed to marijuana, alcohol, and/or cocaine. Pediatrics 1992;89:67-77.

21 Farkas LG, Hainis K, Posnick JC. Anthropometric and anthroposcopic findings of the nasal and facial region in cleft patients before and after primary lip and palate repair. Cleft Palate Craniofac $\mathcal{F}$ 1993;30:1-12.

22 Farkas LG, Posnick JC, Hreczko T. Anthropometry of the head and face in 95 Down syndrome patients. Prog Clin Biol Res 1991;373:53-97.

23 Farkas LG, Ros RB, James J. Anthropometry in lateral facial dysplasia: the bilateral form. Cleft Palate $\mathcal{f}$ 1977;14:41-51.

24 Meaney FJ, Butler MG. The developing role of anthropologists in medical genetics: anthropometric assessment of the Prader-Labhart-Willi syndrome as an illustration. Med Anthropol 1989;10:247-53.

25 Butler MG, Allen A, Haynes JL, Singh DN, Watson MS Brog WR. Anthropometric comparison of mentally retarded males with and without the fragile-X syndrome. Am ₹ Med Genet 1991;38:260-8.

26 Kolar JC, Munro IR, Farkas LG. Anthropometric evaluation of dysmorphology in craniofacial anomalies: Treacher-Collins syndrome. Am $f$ Phys Anthropol 1987;74:441-51.

27 Farkas LG, Kolar JC, Munro IR. Craniofacial disproportions in Apert's syndrome: an anthropometric study. Clef Palate F 1985;22:253-65.

28 Berg MA, Guevara-Aguirre J, Rosenbloom AL, Rosenfeld RG, Francke U. Mutation creating a new splice site in the growth hormone receptor genes of 37 Ecuadorian patients with Laron syndromes. Hum Mutat 1992;1:24-34

29 Greulich WW, Pyle SI. Radiographic atlas of skeletal devel opment of the hand and wrist. 2nd ed. Stanford: Stanford University Press, 1959.

30 Nellhaus G. Head circumferences from birth to eighteen years. Practical composite international and interracial years. Practical composite internation
graphs. Pediatrics 1968;41:106-14.

31 Bookstein FL. The geometry of craniofacial growth invariants. Am f Orthod 1983;83:221-34.

32 Bookstein FL. Describing a craniofacial anomaly: finite 
elements and the biometrics of landmark locations. $A m \mathcal{F}$ Phys Anthropol 1987;74:495-509.

33 Rosenbloom AL, Guevara-Aguirre JG, Rosenfeld RG, Fielder PJ. The little women of Loja - growth hormonereceptor deficiency in an inbred population of southern Ecuador. N Engl f Med 1990;323:1367-74.
34 Guevara-Aguirre J, Rosenbloom AL, Fiedler PJ, Diamond FB Jr, Rosenfeld RG. Growth hormone receptor deficiency in Ecuador: clinical and biochemical phenotype in two populations. J Clin Endocrinol Metab 1993;76:41723. 